\title{
Increased zona-binding ability after incubation of spermatozoa with proteins extracted from spermatozoa of fertile semen
}

\author{
M. Jean ${ }^{1}$, J-L. Dacheux ${ }^{2}$, F. Dacheux ${ }^{3}$, P. Sagot ${ }^{4}$, P. Lopes ${ }^{4}$ and \\ P. Barriere ${ }^{1}$ \\ ${ }^{1}$ Laboratoire de Biologie de la Reproduction, Centre Hospitalier Universitaire de Nantes, Boite Postale \\ 1005, 44035 Nantes Cedex 1, France; ${ }^{2}$ Station de Physiologie de la Reproduction, INRA URA-CNRS \\ 1291. Nouzilly, France; ${ }^{3}$ Laboratoire de Biologie de la Reproduction EA 1365, Tours, France; and \\ ${ }^{4}$ Services de Gynécologie-Obstétrique, Centre Hospitalier Universitaire de Nantes, France
}

\begin{abstract}
The involvement of proteins extracted from spermatozoa of fertile semen in sperm-zona binding was examined under hemizona assay conditions. One droplet of a suspension of spermatozoa was exposed to sperm proteins and then tested for zona binding, while a parallel semen suspension droplet incubated with culture medium served as a control. The reliability of the test was increased by relating the number of spermatozoa bound to each inseminated hemizona to the surface area of the hemizona and expressed as the binding index. For spermatozoa incubated with extracted proteins, the binding index was greater than $(P=0.001)$ that of controls ( $125.2 \pm 45.1$ versus $63.6 \pm 29.2$, respectively). As a first control, two other protein sources (fetal calf serum and human follicular fluid) were tested in the hemizona assay. No significant differences were found in zona binding for other protein-exposed spermatozoa compared with controls. As a second and reverse control, exposure of one hemizona to sperm proteins before insemination with untreated spermatozoa induced a marked decrease $(P=0.0003)$ in sperm binding, compared with that of the matched hemizona not exposed to sperm proteins (control) ( $3.4 \pm 1.4$ versus $74.5 \pm 6.8$, respectively). Taken together, these findings confirm the involvement of extracted sperm proteins in sperm-zona interactions. Therefore, in the cases in which fertilization in vitro fails because of a lack of sperm-zona binding, incubation of deficient spermatozoa with proteins extracted from spermatozoa of fertile ejaculates should restore their ability to interact with the oocyte and, thus, should enhance the prognosis for in vitro fertilization.
\end{abstract}

\section{Introduction}

In vitro fertilization (IVF) is one of the most widely used assisted reproduction procedures for patients with male factor infertility (Acosta et al., 1989). However, sperm dysfunctions associated with abnormalities in the number of spermatozoa, motion parameters or morphology are frequently associated with IVF disorders, i.e., a decreased fertilization rate or complete failure of fertilization (Mahadevan and Trounson, 1984; Jeulin et al., 1986). In such cases, defective sperm-zona pellucida interactions have been recognized as one of the underlying causes of failure to fertilize in IVF (Franken et al., 1993).

Although a defect in oocyte maturity (Tesarik and Testart, 1989) or zona pellucida structure (Gordon, 1990) could prevent sperm-zona binding, there is a selection against abnormal spermatozoa at the zona of the mature oocyte (Liu et al., 1988). This selection results from an inherent inability of the abnormal spermatozoon to bind, or to an active function of the zona, which acts as a barrier against aberrant spermatozoa (Menkveld ef al., 1991). In patients with male factor infertility, semen

Received 6 March 1995.

samples with severe teratozoospermia constitute a heterogeneous population with multiple dysfunctions leading to decreased ability to interact with the zona (Liu et al., 1989).

The ability of spermatozoa to bind to the zona pellucida is related to protein deposition on their surface during transit through the epididymis (Hinrichsen and Blaquier, 1980; Moore et al., 1983; Tezon et al, 1985). These surface proteins mediate gamete recognition by specific and irreversible binding of spermatozoa to complex glycoconjugates of the zona (Oehninger et al., 1991). As reported by Gonzalez-Echeverria et al. (1984) and Blaquier et al. (1987), proteins can be extracted from spermatozoa by exposure to a high ionic strength. These extracted sperm proteins may play a role in sperm-zona binding.

In this study, extracted sperm proteins isolated from normal ejaculates were tested in hemizona assay conditions (Burkman et al., 1988) to determine whether their co-incubation with capacitated spermatozoa would enhance binding to the zona pellucida in vitro. This work was designed to investigate the feasibility of sperm treatment for patients with male factor infertility who fail to fertilize in vitro because of a lack of tight sperm-zona binding. 


\section{Materials and Methods}

\section{Source of extracted sperm proteins}

A standard double-wash, double-centrifugation swim-up procedure as described by Jean $e$ al. (1992) was used to prepare spermatozoa for IVF. Collected mature oocytes were inseminated with $1.0-1.5 \times 10^{5}$ motile spermatozoa in four-well dishes (Nunc, Roskilde) containing $0.5 \mathrm{ml}$ culture medium (BS; Menezo, Biomerieux, Marcy l'Etoile) 3-4 h after retrieval (Jean $e$ al., 1993). This culture medium is supplemented with $10 \mathrm{~g} \mathrm{BSA}^{-1}$.

Eggs were checked for fertilization $20 \mathrm{~h}$ after insemination, after granulosa cells were removed by flushing through a micropipette. Denuded oocytes were examined under a phasecontrast microscope. The presence of two pronuclei in the ooplasm was considered indicative of normal fertilization. In the case of successful fertilization ( $\geq$ one oocyte fertilized), unused (and usually discarded) spermatozoa of the fertile semen were kept $(n=5)$ as a source of extracted sperm proteins.

\section{Extraction of sperm proteins}

After assessment of fertilization, unused spermatozoa (motile and immotile), maintained at room temperature in culture medium, were concentrated by centrifuging the swim-up tube at $300 \mathrm{~g}$ for $5 \mathrm{~min}$. The resulting sperm pellet was suspended in $10 \mathrm{ml}$ PBS (Dulbecco's; GIBCO, Life Technologies Ltd, Paisley) and centrifuged for $10 \mathrm{~min}$ at $300 \mathrm{~g}$ to remove culture medium. Washed spermatozoa were then suspended in $0.6 \mathrm{~mol} \mathrm{KCl}^{-1}$. with $20 \mu \mathrm{mol}$ phenylmethylsulfonylfluoride $\mathrm{l}^{-1}$ (PMSF; Sigma, Saint-Quentin) to prevent possible proteolytic effects, and extracted for $30 \mathrm{~min}$ at $0-4^{\circ} \mathrm{C}$ with occasional stirring (Tezon et al., 1985). The extracted spermatozoa were then pelleted by centrifugation at $10000 \mathrm{~g}$ for $3 \mathrm{~min}$ to obtain a $\mathrm{KCl}$-extract free of residual spermatozoa. For hemizona assay testing, this $\mathrm{KCl}$ extract containing extracted sperm proteins was dialysed extensively against culture medium and stored at $-20^{\circ} \mathrm{C}$ until use.

\section{Quantitative determination of extracted sperm proteins}

The presence of extracted sperm proteins in the $\mathrm{KCl}$ extract was confirmed and its quantitative protein composition was evaluated by determining the total amount of protein for each sample before the hemizona assay.

The bicinchoninic acid protein assay (BCA kit; Pierce, Rockford, IL; Smith et al., 1985) was used for spectrophotometric determination of the concentration of extracted sperm proteins. For each sample, measurement was performed in duplicate.

\section{Hemizona assay protocol}

For the hemizona assay, unfertilized oocytes (confirmed by the absence of pronuclei $20 \mathrm{~h}$ after IVF insemination) were stored in small plastic vials containing $0.5 \mathrm{ml} 1.5 \mathrm{~mol} \mathrm{MgCl}_{2} \mathrm{I}^{-1}$, $0.1 \%(\mathrm{w} / \mathrm{v})$ polyvinylpyrrolidone and $40 \mathrm{mmol}$ Hepes buffer $1^{-1}$ (Sigma) and stored at $4^{\circ} \mathrm{C}$ (Coddington et al., 1992). Before each assay, the required number of oocytes was removed from the storage solution and desalted by thorough rinsing with culture medium.

Oocytes were bisected manually into two hemizonae under a stereomicroscope using hypodermic needles. One of the wells of a four-well dish was partially filled with $0.5 \mathrm{ml}$ culture medium, to serve as a cutting chamber. Unfertilized oocytes were transferred into the cutting well and cut in half by a shearing movement of the needles. The ooplasm inside each hemizona was removed by vigorous pipetting in culture medium. Each matched hemizona was then placed separately in a $0.5 \mathrm{ml}$ droplet of culture medium in a four-well dish and incubated at $37^{\circ} \mathrm{C}\left(5 \% \mathrm{CO}_{2}\right.$ in air). When there are many oocytes to be cut, this procedure (with a little practice) is faster than, and as accurate as, micromanipulator methods (Burkman et al., 1988).

In the hemizona assay, 14 semen samples from patients undergoing IVF were tested for zona binding. The semen characteristics were: $58.4 \pm 15.2 \times 10^{6}$ spermatozoa $\mathrm{ml}^{-1}$, range $37-83 \times 10^{6}$; progressive motility $30.4 \pm 5.4 \%$, range $25-40 \%$; and abnormal forms $55.4 \pm 7.2 \%$, range $47-69 \%$. The mean fertilization rate $(n=14)$ was $51.4 \pm 24.8 \%$, range $0-100 \%$. Because the hemizona assay is an internally controlled bioassay, samples were not selected according to their ability to bind to the zona pellucida during the IVF attempt but according to the number of motile spermatozoa remaining after IVF insemination. The number of motile spermatozoa had to be sufficient $\left(>5 \times 10^{6} \mathrm{ml}^{-1}\right)$ to allow two identical aliquots (control and test) to be obtained and to perform the insemination of eight matched hemizonae in the hemizona assay.

The extracted sperm protein protocol was approved by our institution's Ethics Committee and performed after informed consent was obtained from patients. All specimens studied would normally have been discarded.

Experiment 1: exposure of spermatozoa to extracted sperm proteins. A $0.5 \mathrm{ml}$ droplet of the sperm suspension $\left(5 \times 10^{6}\right.$ motile spermatozoa $\mathrm{ml}^{-1}$ ) was exposed to extracted sperm proteins at $0.5 \mathrm{mg} \mathrm{ml}^{-1}$ for $3 \mathrm{~h}$ at room temperature, while a parallel semen droplet incubated with culture medium served as a control. Spermatozoa were exposed to extracted sperm proteins and then centrifuged at $400 \mathrm{~g}$ for $5 \mathrm{~min}$ to remove incubation medium containing unfixed extracted sperm proteins. After three washes and centrifugations in fresh culture medium, the final pellet was suspended in $0.5 \mathrm{ml}$ culture medium, and sperm concentration was evaluated to form $0.05 \mathrm{ml}$ droplets containing $2 \times 10^{4}$ motile spermatozoa. Washing and counting were performed under the same conditions for the control.

One hemizona was placed in a droplet with spermatozoa exposed to extracted sperm proteins, while the matching hemizona was placed in the droplet with spermatozoa that were not exposed to extracted sperm proteins (control). After $4 \mathrm{~h}$ of co-incubation $\left(37^{\circ} \mathrm{C}\right.$ in $5 \% \mathrm{CO}_{2}$ in air), each hemizona was removed and rinsed in fresh culture medium, using a finely drawn pipette to separate loosely attached spermatozoa (Burkman et al., 1988). After fixation in $2 \%(\mathrm{v} / \mathrm{v})$ glutaraldehyde (Sigma) in PBS, hemizonae were mounted separately on microscope slides, and the number of tightly bound spermatozoa was
Downloaded from Bioscientifica.com at $04 / 267202310: 00: \theta 7 \mathrm{AM}$ 
counted under an inverted microscope fitted with a video system.

Because the two halves of the hemizona could not be of equal size, surface evaluation was performed for each matched hemizona to increase the reliability of the hemizona assay. This evaluation, expressed as the number of surface units of each hemizona observed at a constant magnification $(\times 200)$, was performed directly on a video screen covered with a transparent grid divided into $1 \mathrm{~cm} \times 1 \mathrm{~cm}$ squares. The number of tightly bound spermatozoa was thus related to the surface area of the hemizona. The binding index (BI) was defined as follows:

$$
\mathrm{BI}=\frac{\begin{array}{l}
\text { total number of tightly-bound spermatozoa } \\
\text { on the hemizona }
\end{array}}{\text { total number of surface units of the hemizona }} \times 100
$$

Experiment 2: exposure of spermatozoa to other protein sources To assess the sperm-specific effect of extracted sperm proteins on zona binding, fetal calf serum (FCS; I.J.B., Reims) and human follicular fluid (hFF) were subjected to the same preparative procedure as extracted sperm proteins and then tested in the hemizona assay. The hFF sample was collected at the time of oocyte retrieval from a patient undergoing IVF treatment. This sample, free of any contamination with red blood cells, was centrifuged at $1000 \mathrm{~g}$ for $10 \mathrm{~min}$ to remove granulosa cells and then stored at $-20^{\circ} \mathrm{C}$.

The total protein contents of FCS and hFF were adjusted to $0.5 \mathrm{mg} \mathrm{ml}^{-1}$ and $5.0 \mathrm{mg} \mathrm{ml} \mathrm{m}^{-1}$ by dilution with culture medium. A $0.5 \mathrm{ml}$ droplet of a sperm suspension $\left(5 \times 10^{6}\right.$ motile spermatozoa) was exposed to hFF or FCS at $0.5 \mathrm{mg} \mathrm{ml}^{-1}$ and $5.0 \mathrm{mg} \mathrm{ml}^{-1}$ for $3 \mathrm{~h}$ at room temperature, while a semen droplet incubated with culture medium served as a control. Washing of spermatozoa and the hemizona assay procedure were then performed as described above.

Experiment 3: exposure of zona to extracted sperm proteins. To evaluate the involvement of extracted sperm proteins with sperm-zona binding, a reverse control was performed using hemizona assay. One hemizona was incubated with extracted sperm proteins at $0.5 \mathrm{mg} \mathrm{ml}^{-1}$, while the matching hemizona was incubated in culture medium (control). After incubation for $3 \mathrm{~h}$ at room temperature, each hemizona was removed and rinsed in fresh culture medium.

Droplets $(0.05 \mathrm{ml})$ containing $2 \times 10^{4}$ untreated (not exposed to ESP) motile spermatozoa were placed with each hemizona. The gametes were then co-incubated in culture medium for $4 \mathrm{~h}$ at $37^{\circ} \mathrm{C}\left(5 \% \mathrm{CO}_{2}\right.$ in air). Evaluation of tightly bound spermatozoa was performed as described above.

\section{Statistical analysis}

For each hemizona assay, results are expressed as the mean of $\mathrm{BI} \pm \mathrm{SD}$ noted for the pairs of hemizona assessed. The paired Student's $t$ test and the Mann-Whitney $U$ test were used to analyse hemizonal data. Probability values of $<0.05$ were considered statistically significant.

\section{Results}

The parameters for the fertile semen $(n=5)$ that served as extracted sperm protein sources are shown (Table 1). Sperm characteristics were considered normal (WHO criteria).

\section{Experiment 1: exposure of spermatozoa to extracted sperm proteins}

The results of the hemizona assay for spermatozoa exposed to extracted sperm proteins or to culture medium (control) are presented (Table 2 ). For each hemizona assay $(n=8)$, results are expressed as the mean of $\mathrm{BI} \pm \mathrm{SD}$ calculated for the hemizonae of each group (control and ESP; Fig. 1).

In all cases, when the means of the $\mathrm{BI}$ for both groups (control and ESP) were compared, tight sperm-zona binding appeared to be significantly greater $(P<0.05)$ for spermatozoa exposed to extracted sperm proteins than for controls.

Table 1. Semen parameters and amounts of extracted sperm proteins (ESP) for $\mathrm{KCl}$-extracted fertile ejaculates $(n=5)$

\begin{tabular}{lcc}
\hline & Mean $\pm \mathrm{SD}$ & Range \\
\hline $\begin{array}{l}\text { Number of spermatozoa } \\
\left(\times 10^{6} \mathrm{~m}^{-1}\right)\end{array}$ & $64.6 \pm 16.8$ & $46-88$ \\
Progressive motility (\%) & $35.0 \pm 5.0$ & $30-40$ \\
Abnormal forms (\%) & $56.6 \pm 9.2$ & $45-67$ \\
ESP $\left(\mu \mathrm{g} \mathrm{ml}^{-1}\right)$ & $833.8 \pm 156.7$ & $622.0 \pm 1003.5$ \\
\hline
\end{tabular}

Table 2. Comparison of hemizona assay (HZA) results for spermatozoa exposed to extracted sperm proteins (ESP) or

\begin{tabular}{|c|c|c|c|c|}
\hline \multirow{2}{*}{$\begin{array}{l}\mathrm{HZA} \\
\text { number }\end{array}$} & \multirow{2}{*}{$\begin{array}{c}\text { Number of pairs } \\
\text { of hemizona } \\
\text { assessed }\end{array}$} & \multicolumn{2}{|c|}{ Binding index ${ }^{a}(B I)$} & \multirow[b]{2}{*}{$P$ value } \\
\hline & & Control & ESP & \\
\hline 1 & 5 & $\begin{array}{r}20.5 \pm 20.7 \\
(2.9-53.7)\end{array}$ & $\begin{array}{l}61.1 \pm 26.3 \\
(19.7-84.6)\end{array}$ & 0.01 \\
\hline 2 & 4 & $\begin{array}{l}51.5 \pm 17.2 \\
(40.3-67.4)\end{array}$ & $\begin{array}{l}99.4 \pm 22.4 \\
(73.9-124.5)\end{array}$ & 0.001 \\
\hline 3 & 5 & $\begin{array}{l}57.7 \pm 20.1 \\
(24.0-75.0)\end{array}$ & $\begin{array}{c}116.1 \pm 35.5 \\
(83.6-174.3)\end{array}$ & 0.05 \\
\hline 4 & 5 & $\begin{array}{l}59.4 \pm 19.6 \\
(35.8-79.4)\end{array}$ & $\begin{array}{c}144.6 \pm 62.8 \\
(87.3-212.5)\end{array}$ & 0.01 \\
\hline 5 & 7 & $\begin{array}{l}62.3 \pm 39.5 \\
(15.2-108.3)\end{array}$ & $\begin{array}{l}96.6 \pm 59.9 \\
(35.5-195.4)\end{array}$ & 0.02 \\
\hline 6 & 4 & $\begin{array}{l}61.2 \pm 25.6 \\
(40.0-95.12)\end{array}$ & $\begin{array}{c}113.1 \pm 35.5 \\
(80.4-154.3)\end{array}$ & 0.02 \\
\hline 7 & 5 & $\begin{array}{l}70.6 \pm 28.9 \\
(50.0-120.8)\end{array}$ & $\begin{array}{c}165.3 \pm 68.1 \\
(92.1-276.6)\end{array}$ & 0.01 \\
\hline 8 & 4 & $\begin{array}{c}125.6 \pm 57.7 \\
(87.3-210.5)\end{array}$ & $\begin{array}{l}205.5 \pm 42.2 \\
(161.2-259.1)\end{array}$ & 0.02 \\
\hline Mean \pm SD & & $63.6 \pm 29.2$ & $125.2 \pm 45.1$ & 0.001 \\
\hline
\end{tabular}
culture medium (control)

${ }^{a}$ Values are means $\pm \mathrm{SD}$ (range).

Downloaded from Bioscientifica.com at 04/26/2023 10:00:07AM 
(a)

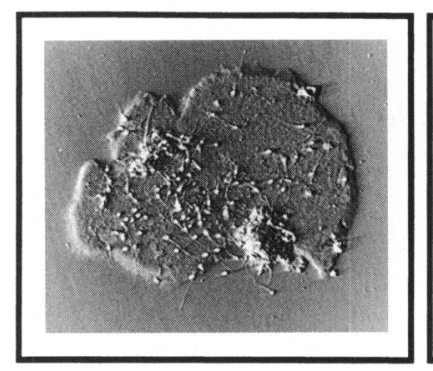

(b)

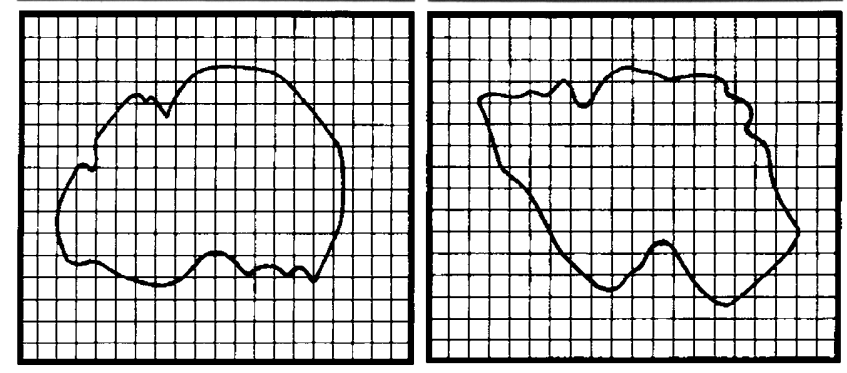

Fig. 1. Expression of tight sperm-zona pellucida binding for (a) control and (b) spermatozoa exposed to extracted sperm proteins in the hemizona assay. For each hemizona, the number of bound spermatozoa (79 in control; 244 in ESP-exposed) was divided by the number of spermatozoa per surface unit for the hemizona 98 in control; 91 in ESP-exposed) and expressed as the binding index (80.6 in control; 268.1 in ESP-exposed).

\section{Experiment 2: exposure of spermatozoa to other protein sources}

When spermatozoa were exposed to other protein sources ( $\mathrm{hFF}$ and FCS) at two different concentrations $\left(0.5 \mathrm{mg} \mathrm{ml} \mathrm{m}^{-1}\right.$ and $5.0 \mathrm{mg} \mathrm{ml}^{-1}$ ) and tested for zona binding in the hemizona assay, no significant differences were found between spermatozoa exposed to protein and controls (Table 3).

\section{Experiment 3: exposure of zona to extracted sperm proteins}

Exposure of one hemizona to extracted sperm proteins before insemination with untreated spermatozoa caused a significant decrease $(P=0.0003)$ in sperm binding compared with results for the matched hemizona not exposed to extracted sperm proteins (control) (Table 4).

\section{Discussion}

The isolation of extracted sperm proteins from fertile semen allowed evaluation of their role in sperm-zona binding in hemizona assay conditions. When spermatozoa tested by the hemizona assay were exposed to extracted sperm proteins at $0.5 \mathrm{mg} \mathrm{ml}^{-1}$, their tight sperm-zona binding was significantly greater $(P=0.001)$ than that of controls exposed to culture medium containing $10 \mathrm{~g} \mathrm{BSA} \mathrm{l}^{-1}$. Because the protein concentration of controls was 20 times greater than that of the extracted sperm proteins tested, the high binding index for spermatozoa exposed to extracted sperm proteins could not be related to an improvement in sperm capacitation. Spermatozoa exposed to extracted sperm proteins were then exposed to two other protein sources ( $\mathrm{hFF}$ and FCS) and tested in the hemizona assay to evaluate the specific effect of extracted sperm proteins in zona-binding enhancement. Even at $5 \mathrm{mg} \mathrm{ml}^{-1}$ (i.e. ten times the concentration of the extracted sperm proteins tested), the other protein sources had no effect on the zona binding of spermatozoa. Moreover, the marked decrease in sperm binding observed that zona exposure to extracted sperm proteins indicated that binding of extracted sperm proteins was more specific to the zona than to spermatozoa, confirming the involvement of extracted sperm proteins in sperm-zona interactions. Incubation of zona pellucida with extracted sperm proteins apparently blocked sperm-zona binding because the proteins occupied binding sites on the zona pellucida.

These findings provide evidence of the involvement of sperm proteins extracted by $0.6 \mathrm{~mol} \mathrm{KCl} \mathrm{l^{-1 }}$ from fertile semen in the sperm-egg interaction. According to Blaquier et al. (1987), proteins extracted from spermatozoa by using $0.6 \mathrm{~mol} \mathrm{KCl}^{-1}$ are probably removed from the surface of the cells, since the ionic strength is not sufficient to extract integral proteins from the plasma membrane of the spermatozoon (Cameo et al., 1990). Therefore, sperm proteins extracted with $\mathrm{KCl}$ could accumulate on the sperm surface during epididymal transit and then play a role in gamete interaction. Even after the

Table 3. Comparison of hemizona assay (HZA) results for spermatozoa exposed to human follicular fluid (hFF) and fetal calf serum (FCS) or culture medium (control)

\begin{tabular}{|c|c|c|c|c|c|}
\hline \multirow{2}{*}{$\begin{array}{l}\mathrm{HZA} \\
\text { number }\end{array}$} & \multirow{2}{*}{$\begin{array}{c}\text { Number of pairs } \\
\text { of hemizona } \\
\text { assessed }\end{array}$} & \multirow{2}{*}{$\begin{array}{c}\text { Source of } \\
\text { proteins }\end{array}$} & \multicolumn{2}{|c|}{ Binding index ${ }^{a}(B I)$} & \multirow[b]{2}{*}{$P$ value } \\
\hline & & & Control & Proteins & \\
\hline \multirow[t]{2}{*}{1} & 6 & $\begin{array}{c}\text { FCS } \\
\left(0.5 \mathrm{mg} \mathrm{ml}^{-1}\right)\end{array}$ & $\begin{array}{c}74.6 \pm 87.3 \\
(3.1-244.4)\end{array}$ & $\begin{array}{c}69.6 \pm 85.8 \\
(1.4-237.6)\end{array}$ & 0.12 \\
\hline & 6 & $\begin{array}{c}\text { FCS } \\
\left(5.0 \mathrm{mg} \mathrm{ml}^{-1}\right)\end{array}$ & $\begin{array}{l}89.9 \pm 74.6 \\
(28.8-152.7)\end{array}$ & $\begin{array}{l}81.9 \pm 57.8 \\
(22.2-171.2)\end{array}$ & 0.65 \\
\hline \multirow[t]{2}{*}{2} & 5 & $\begin{array}{c}\mathrm{hFF} \\
\left(0.5 \mathrm{mg} \mathrm{ml}^{-1}\right)\end{array}$ & $\begin{array}{l}62.2 \pm 39.9 \\
(29.8-108.3)\end{array}$ & $\begin{array}{l}35.2 \pm 10.7 \\
(27.2-53.5)\end{array}$ & 0.23 \\
\hline & 7 & $\begin{array}{c}\mathrm{hFF} \\
\left(5.0 \mathrm{mg} \mathrm{ml}^{-1}\right)\end{array}$ & $\begin{array}{l}64.2 \pm 42.5 \\
(10.5-123.4)\end{array}$ & $\begin{array}{c}74.2 \pm 53.0 \\
(9.8-152.9)\end{array}$ & 0.18 \\
\hline
\end{tabular}

"Values are means $\pm \mathrm{SD}$ (range). 
Table 4. Evaluation of zona binding for untreated spermatozoa after exposure of one hemizona to extracted sperm proteins (ESP) and the matching hemizona to culture medium (control)

\begin{tabular}{|c|c|c|c|c|}
\hline \multirow{2}{*}{$\begin{array}{l}\text { HZA } \\
\text { number }\end{array}$} & \multirow{2}{*}{$\begin{array}{c}\text { Number of pairs } \\
\text { of hemizona } \\
\text { assessed }\end{array}$} & \multicolumn{2}{|c|}{ Binding index ${ }^{a}(\mathrm{BI})$} & \multirow[b]{2}{*}{$P$ value } \\
\hline & & Control & ESP & \\
\hline 1 & 8 & $\begin{array}{l}68.7 \pm 14.2 \\
(43.2-92.3)\end{array}$ & $\begin{array}{l}3.9 \pm 1.7 \\
(2.0-7.5)\end{array}$ & 0.0001 \\
\hline 2 & 7 & $\begin{array}{l}70.5 \pm 15.8 \\
(52.4-92.3)\end{array}$ & $\begin{array}{l}2.4 \pm 1.3 \\
(1.2-4.5)\end{array}$ & 0.0001 \\
\hline 3 & 8 & $\begin{array}{l}74.9 \pm 31.5 \\
(15.5-100.0)\end{array}$ & $\begin{array}{l}5.2 \pm 2.6 \\
(1.7-9.1)\end{array}$ & 0.0004 \\
\hline 4 & 4 & $\begin{array}{l}84.0 \pm 25.2 \\
(57.1-117.5)\end{array}$ & $\begin{array}{l}2.3 \pm 0.9 \\
(1.5-3.2)\end{array}$ & 0.007 \\
\hline Mean \pm SD & & $74.5 \pm 6.8$ & $3.4 \pm 1.4$ & 0.0003 \\
\hline
\end{tabular}

HZA: hemizona assay.

${ }^{2}$ Values are means \pm SD (range).

$\mathrm{KCl}$ extraction procedure, the extracted sperm proteins involved in zona binding retained their biological activity and could bind to the plasma membrane of the spermatozoon. Therefore, as observed in hamsters (Gonzalez-Echeverria et al., 1984), extracted sperm proteins are apparently transferred onto the surface of tested spermatozoa during the hemizona assay, which would account for their increased ability to bind to the zona pellucida. Although extracted sperm proteins were extracted from whole spermatozoa, the head is the probable origin because of the role played by this region in zona binding.

There are two possible explanations for the increased binding capacity observed with spermatozoa exposed to extracted sperm proteins. A single fertile ejaculate, depending on the heterogeneity of the spermatozoa, could contain a subpopulation of immature spermatozoa, characterized by a significant decrease in the amount or localization of extracted sperm proteins present on their surface. This hypothesis was reported by Blaquier et al. (1987) to establish a relationship between the altered localization of epididymal antigens on spermatozoa and infertility in some men. Extracted sperm proteins could have been transferred onto the membrane of these spermatozoa without extracted sperm proteins, thus accounting for their increased binding ability in the hemizona assay. Another possible explanation is that specific receptor sites for extracted sperm proteins are not completely saturated on the plasma membranes of spermatozoa after their transit through the epididymis, allowing additional extracted sperm proteins to bind.

The results presented here do not define the characteristics of the putative molecules involved in mediating or enhancing sperm-zona binding but suggest that extracted sperm proteins should improve gamete interaction for spermatozoa that fail to bind to the oocyte during IVF. Tight binding of spermatozoa to the zona pellucida is one of the most significant factors in predicting successful human fertilization in vitro, and only a few cases of male factor IVF failure have pointed exclusively to defects occurring after binding (Tesarik and Testart, 1989). This finding reinforces the predictive significance of measurements of tight binding of spermatozoa in IVF prognosis (Oehninger et al., 1991).

Therefore, for patients with severe male factor infertility, who fail to fertilize in vitro because of a defect in tight sperm-zona binding, incubation of spermatozoa with extracted sperm proteins from fertile semen should improve their ability to interact with the oocyte and thus improve the prognosis for IVF.

Prospective randomized studies in male factor infertile patients undergoing IVF are required to provide further evidence of the efficacy of such treatment of spermatozoa. However, the ethics of this 'sperm protein donation' is of major importance, especially with reference to the potential for transmission of viral constituents.

The characterization of these extracted proteins, currently being conducted in our laboratory, may provide insight into normal sperm physiology as well as insights into pathological processes that result in clinical infertility.

Although micromanipulation-assisted fertilization procedures are being used more frequently, the study reported here suggests a novel means of managing male factor infertility by counteracting the influence of a specific sperm defect, thereby optimizing the use of IVF as a treatment for male infertility.

The authors thank P. Jean for photographic assistance.

\section{References}

Acosta AA, Oehninger S, Morshedi M, Swanson RJ, Scott R and Iriani F (1989) Assisted reproduction and treatment of the male factor Obstetric and Gynecologic Surveys 44 1-18

Blaquier JA, Cameo MS, Stephany D, Piazza A, Tezon J and Sherins RJ (1987) Abnormal distribution of epididymal antigens on spermatozoa from infertile men Fertility and Sterility 47302-309

Burkman LJ, Coddington CC, Franken DR, Kruger TF, Rosenwaks $Z$ and Hodgen GD (1988) The hemizona assay (HZA): development of a diagnostic test for the binding of human spermatozoa to the human hemizona pellucida to predict fertilization potential Fertility and Sterility 49688-697

Cameo MS, Dawidowski A, Sanjurjo C, Gonzalez-Echeverria $F$ and Blaquier JA (1990) Changes in sperm-specific antigens during epididymal maturation. In Gamete Interaction: Prospects for Immunocontraception, pp 129-141 Eds NJ Alexander, D Griffin, JM Spieler and GMH Waites. Wiley-Liss, Inc, New York

Coddington $\mathrm{CC}$, Alexander NJ, Fulgham D, Mahony $\mathrm{M}$, Johnson $\mathrm{D}$ and Hodgen GD (1992) Hemizona assay (HZA) demonstrates effects of characterized mouse antihuman sperm antibodies on sperm zona binding Andrologia $24271-277$

Franken DR, Acosta AA, Kruger TF, Lombard CJ, Oehninger S and Hodgen GD (1993) The hemizona assay: its role in identifying male factor infertility in assisted reproduction Fertility and Sterility 59 1075-1080

Gonzalez-Echeverria F, Cuaniscu P, Piazza A, Pineiro L and Blaquier J (1984) Addition of an androgen-free epididymal protein extract increases the ability of immature hamster spermatozoa to fertilize in vivo and in vitro Journal of Reproduction and Fertility 71 433-437

Gordon JW (1990) Zona drilling: a new approach to male infertility Journal of In Vitro Fertilization and Embryo Transfer 7 223-228

Hinrichsen MJ and Blaquier JA (1980) Evidence supporting the existence of sperm maturation in the human epididymis Joumal of Reproduction and Fertility 60 291-294

Jean M, Barriere P, Sagot P, L'hermite A and Lopes P (1992) Utility of zona pellucida drilling in cases of severe semen alterations in man Fertility and Sterility $\mathbf{5 7} 591-596$ 
Jean M, Sagot P, Nomballais MF, Lopes P, Julou V and Barriere P (1993) Medical abortion after in vitro assisted fertilization Fertility and Sterility 60 359-360

Jeulin C, Feneux D and Serres C (1986) Sperm factors related to failure of human in vitro fertilization Journal of Reproduction and Fertility 76 735-744

Liu DY, Lopata A, Johnston WIH and Baker WHG (1988) A human sperm-zona pellucida binding test using oocytes that failed to fertilize in vitro Fertility and Sterility $50782-788$

Liu DY, Lopata A, Johnston WIH and Baker WHG (1989) Human sperm zona pellucida binding, sperm characteristics and in vitro fertilization Human Reproduction 4 696-701

Mahadevan MM and Trounson AO (1984) The influence of seminal characteristics on the success rate of human in vitro fertilization Fertility and Sterility 42 400-405

Menkveld R, Franken DR, Kruger TF, Oehninger S and Hodgen GD (1991) Sperm selection capacity of the human zona pellucida Molecular Reproduction and Development $30346-352$
Moore HDM, Hartman TD and Pryor JP (1983) Development of the oocytepenetrating capacity of spermatozoa in the human epididymis International Journal of Andrology 6 310-318

Oehninger S, Veeck L, Franken D, Kruger TF, Acosta AA and Hodgen GD (1991) Human preovulatory oocytes have a higher sperm-binding ability than immature oocytes under hemizona assay conditions: evidence supporting the concept of "zona maturation" Fertility and Sterility 55 1165-1170

Smith PK, Krohn RI, Hermanson GT, Mallia AK, Gartner FH and Provenzano MD (1985) Measurement of protein using bicinchoninic acid Analytical Biochemistry 150 76-85

Tesarik J and Testart J (1989) Human sperm-egg interactions and their disorders: implication in the management of infertility Human Reproduction 4 729-741

Tezon JG, Ramella E, Cameo MS, Vazquez MH and Blaquier JA (1985) Immunochemical localization of secretory antigens in the human epididymis and their association with spermatozoa Biology of Reproduction 32 591-597 